\title{
Suppression of Hypothalamic-Pituitary-Adrenal Axis Responsiveness to Stress in a Rat Model of Acute Cholestasis
}

\author{
Mark G. Swain, Vladimir Patchev, ${ }^{\star}$ John Vergalla, George Chrousos, ${ }^{\star}$ and E. Anthony Jones \\ Liver Diseases Section, National Institute of Diabetes and Digestive and Kidney Diseases; and *Developmental Endocrinology Branch, \\ National Institute of Child Health and Human Development, National Institutes of Health, Bethesda, Maryland, 20892
}

\begin{abstract}
Cholestatic patients undergoing surgery have increased mortality and demonstrate clinical features suggestive of adrenal insufficiency. To examine whether cholestasis influences the status of the hypothalamic-pituitary-adrenal axis, we evaluated rats with acute cholestasis caused by bile duct resection (BDR) and sham-operated and unoperated controls. Basal unstressed plasma concentrations of ACTH and corticosterone were similar in BDR and sham-operated and unoperated control rats. However, exposure of BDR rats to saturated ether vapor resulted in significantly less ACTH and corticosterone release in plasma than in the control animals. To understand the mechanism(s) of decreased HPA axis responsiveness to ether stress in cholestasis, we administered corticotropin-releasing factor (CRF) and measured hypothalamic content, mRNA levels and in vitro secretion of CRF and arginine vasopressin (AVP), the two principal secretagogues of ACTH. In BDR animals, ACTH responses to CRF were decreased and hypothalamic content of CRF and CRF mRNA expression in the paraventricular nucleus were decreased by 25 and 37\%, respectively. Furthermore, CRF release from hypothalamic explants of BDR rats was $23 \%$ less than that of controls. In contrast to CRF, hypothalamic content of AVP was 35\% higher, AVP mRNA in the paraventricular nucleus was increased by 6.6-fold, and hypothalamic explant release of AVP was $24 \%$ higher in BDR rats than in control animals. Pituitary ACTH contents were similar in BDR and sham resected rats, but higher than unoperated controls. These findings demonstrate that acute cholestasis in the rat is associated with suppression of hypothalamic-pituitaryadrenal axis responsiveness to stress and demonstrate a dissociation between mechanisms of ACTH regulation mediated by CRF and AVP. (J. Clin. Invest. 1993. 91:1903-1908.) Key words: corticotropin releasing factor $\bullet$ corticosterone $\bullet$ cholestasis • ACTH
\end{abstract}

\section{Introduction}

Increased perioperative morbidity and mortality are well recognized in patients with cholestasis, and are associated with hypovolemia, hypotension, and renal failure (1-3). These complications of cholestasis resemble the clinical features of adrenal insufficiency (4). In addition, in provocative stress testing,

Address correspondence and reprint requests to Mark G. Swain, M.D., Liver Diseases Section, National Institutes of Health, Building 10, Room 4D-52, Bethesda, MD 20892.

Received for publication 13 July 1992 and in revised form 4 December 1992.

The Journal of Clinical Investigation, Inc.

Volume 91, May 1993, 1903-1908 $\sim 25 \%$ of alcoholic cirrhotics have been shown to have impaired responsiveness of the hypothalamic-pituitary-adrenal (HPA) ${ }^{1}$ axis (5). It seemed possible, therefore, that hyporesponsiveness of the HPA axis might contribute to the apparently enhanced vulnerability of cholestatic patients to surgical stress. Obstructive jaundice in humans and animals has been associated with the accumulation in plasma of a number of substances, which are known to interact with the HPA axis, including cytokines $(6,7)$ and endogenous opioids $(8,9)$, and which may influence the basal or stress related activity of this axis.

Hypothalamic corticotropin-releasing factor (CRF), produced by the median division of the paraventricular nucleus (PVN), has been shown to be the principal, permissive regulator of ACTH secretion from the anterior pituitary (10). Arginine vasopressin (AVP), produced by parvocellular neurons of the PVN and from collaterals of magnocellular neurons terminating in the median eminence, is also a major coregulator of pituitary ACTH secretion. AVP acts synergistically with CRF to augment ACTH release (11). Based on observations made in cholestatic patients undergoing surgery, we postulated that cholestatic rats may have reduced responsiveness of the HPA axis to stress. To test this hypothesis, we studied the basal status of the HPA axis and its responsiveness to ether stress in the bile duct-resected (BDR) rat model of cholestasis and parallel sham-resected and unoperated controls. We documented a diminished responsiveness of the HPA axis to acute stress in BDR animals.

\section{Methods}

Animals. Male Sprague-Dawley rats weighing 190-210 g were obtained from Taconic Farms Inc., (Germantown, NY). All animals were housed two per cage in a light controlled room maintained at $22^{\circ} \mathrm{C}$ with a 12-h day/night cycle and were given free access to food and water. The rats were handled regularly.

Model of acute cholestasis. Laparotomy was performed under general anesthesia induced by intraperitoneal injection of ketamine $\mathrm{HCl}$ $(50 \mathrm{mg} / \mathrm{ml})$ (Parke-Davis, Morris Plains, NJ) and xylazine ( $100 \mathrm{mg} /$ ml) (Fermenta Animal Health Co., Kansas City, MO), 8:1, vol/vol, dose $0.2-0.3 \mathrm{ml} / \mathrm{rat}$. The bile duct was isolated, doubly ligated, and resected between the ligatures as described by Cameron and Oakley (12). Sham resection consisted of laparotomy and bile duct identification and manipulation without ligation or resection. Unoperated agematched rats also served as controls. Experiments were performed $5 \mathrm{~d}$ after surgery.

Model of stress. To activate the HPA axis and stimulate ACTH and corticosterone release, rats were exposed to saturated ether vapor, a

1. Abbreviations used in this paper: AVP, arginine vasopressin; BDR, bile duct resected; CRF, corticotropin-releasing factor; HPA, hypothalamic-pituitary-adrenal; PVN, paraventricular nucleus; SCN, suprachiasmatic; SON, supraoptic. 
well-described systemic stressor, for $1 \mathrm{~min}$. Ether vapor has been shown to activate the HPA axis in part by stimulating CRF release from the hypothalamus (13).

Ovine CRF administration. To examine the responsiveness of the corticotroph to CRF, we administered ovine CRF intraperitoneally to bile duct-resected and sham-resected rats $(2.0 \mu \mathrm{g} / 200 \mathrm{~g}$ in $0.5 \mathrm{ml}$ normal saline) (Peninsula Labs, Inc., Belmont, CA) and measured truncal blood ACTH levels 30 min later.

Blood and tissue samples. All rats were killed by decapitation between 9:00 a.m. and 11:00 a.m. to obviate effects of the circadian rhythm of ACTH and corticosterone levels on the results. Rats were killed within $30 \mathrm{~s}$ after removal from their cage for the determination of basal hormone levels in the unstressed state, and 2 and $20 \mathrm{~min}$ after exposure to ether vapor for the determination of plasma ACTH and corticosterone levels, respectively; i.e. when the respective plasma levels are maximal (Swain, M. G., unpublished observation) (14). Truncal blood was collected into prechilled EDTA-containing plastic tubes for ACTH and corticosterone determination. Blood samples were centrifuged immediately at $1,000 \mathrm{~g}$ for $12 \mathrm{~min}$ and plasma was stored at $-70^{\circ} \mathrm{C}$ until assayed.

Adrenal glands were removed, trimmed free from fat, and weighed. Pituitary glands were rapidly removed from the skull, the anterior pituitary was separated, placed in a plastic tube on ice, and immediately frozen at $-70^{\circ} \mathrm{C}$. It was subsequently homogenized in $500 \mu \mathrm{l} 0.1 \mathrm{~N} \mathrm{HCl}$ and the homogenate was lyophilized.

Hypothalami were dissected out on ice. The tissue blocks were defined rostrally by the posterior border of the optic chiasm, caudally by the anterior border of the mammillary bodies, laterally by the hypothalamic fissures, dorsally by the roof of the third ventricle, and ventrally by the stalk-sectioned infundibulum. To determine total hypothalamic CRF and AVP concentrations, hypothalami were extracted and homogenized in $1.0 \mathrm{ml}$ of ice-cold $0.1 \mathrm{~N} \mathrm{HCl}$ and centrifuged for $20 \mathrm{~min}$ at $3,000 \mathrm{~g}$ at $4^{\circ} \mathrm{C}$. Supernatants were lyophylized and stored at $-70^{\circ} \mathrm{C}$ until assayed for CRF/AVP contents.

For the determination of hypothalamic basal CRF release in vitro, hypothalamic organ explants were collected in ice-cold Medium 199 with modified Earle's salt (Gibco Laboratories, Grand Island, NY) containing $0.1 \% \mathrm{BSA}, 100 \mathrm{KIU} / \mathrm{ml}$ aprotinin, $20 \mu \mathrm{M}$ bacitracin, and $0.005 \%$ ascorbic acid (all reagents from Sigma Immunochemicals, St. Louis, MO). After preincubation for $2 \mathrm{~h}$ at $38^{\circ} \mathrm{C}$ in an atmosphere of 95\% oxygen / $5 \%$ carbon dioxide in a water-jacketed incubator, single tissue explants were transferred to plastic mesh baskets and incubated for two successive periods of $20 \mathrm{~min}$ in $0.5 \mathrm{ml}$ of medium (as above) in 48-multiwell cell culture plates (Costar Corp., Cambridge, MA). Basal release was determined from the superfusate of the second incubation. At the end of the experiment, each explant was exposed for $20 \mathrm{~min}$ to a depolarizing concentration of $\mathrm{KCl}(60 \mathrm{mM})$ to assess the intactness of the tissue (15). Superfusates were stored at $-70^{\circ} \mathrm{C}$ until assayed for CRF/AVP content.

Hormone radioimmunoassays. Plasma corticosterone was determined by radioimmunoassay using commercially available reagents (ICN Biomedicals Inc., Costa Mesa, CA). Each plasma sample was diluted 1:200 and 100- $\mu$ l aliquots were assayed in duplicate. Results were expressed as nanograms per milliter of plasma. Within-assay coefficient of variation was $7 \%$ and interassay variation $10 \%$. The ACTH radioimmunoassay was also conducted using commercially available reagents (INCSTAR, Stillwater, MN). Each sample was assayed in duplicate. For assays of ACTH in pituitary, lyophilized specimens were reconstituted with $500 \mu$ l double distilled water and assayed after appropriate dilution. Protein was assayed by the Lowry method (16). Results were expressed as picograms of ACTH per milliter of plasma or nanograms of ACTH per milligram of pituitary protein. Within-assay coefficient of variation was $12 \%$ and the interassay coefficient of variation was $16 \%$.

Radioimmunoassay of CRF was performed as described previously, using a specific anti-CRF serum developed in our laboratory (15). For the determination of hypothalamic CRF content, lyophylized samples were reconstituted in $1.0 \mathrm{ml} 0.63 \mathrm{M}$ sodium phosphate buffer ( $\mathrm{pH} 7.4$ ) containing $0.013 \mathrm{M}$ EDTA, $0.1 \%$ Triton $\mathrm{X}-100$ and $0.02 \%$ sodium azide (all from Sigma Immunochemicals) and subsequently diluted 1:40 in this buffer before assay. CRF concentrations in hypothalamic explant superfusion media were determined directly. Results are expressed as picograms of CRF released per milliter of media or picograms CRF per milligram of hypothalamic protein.

Radioimmunoassay of AVP in hypothalamic tissue extracts and superfusates were carried out using a specific anti-AVP serum (Arnel Inc., New York, NY) at a final dilution of 1:90,000 and ${ }^{125}$ I-labeled AVP (New England Nuclear-Dupont, Wilmington, DE) as tracer. Antibody bound hormone was separated by second antibody precipitation (Arnel). $\mathrm{ED}_{50}$ of this assay was $36.2 \pm 5.2 \mathrm{pg} / \mathrm{ml}$ and intra- and interassay coefficients of variation were 9 and $22 \%$, respectively. AVP content of hypothalamic explant superfusates was determined directly. Before measurement of hypothalamic AVP content, lyophylized samples were reconstituted (as above for CRF) and subsequently diluted 1:800. Results are expressed as picograms of AVP per milligrams of hypothalamic protein or picograms of AVP per milliliter media.

In situ hybridization. In situ hybridization for CRF/AVP mRNA expression was performed as previously described (17). Rats were sacrificed by decapitation. Their brains were rapidly removed, frozen by immersion in 2-methyl butane at $-30^{\circ} \mathrm{C}$ and stored at $-70^{\circ} \mathrm{C}$ until dissection. Synthetic 48-base oligonucleotide probes (kindly donated by Dr. W. S. Young, Laboratory of Cell Biology, National Institute of Mental Health) were directed against bases 1,009-1,056, encoding the 16 terminal amino acids of the pro-AVP glycoprotein moiety (18) and against CRF bases 496-543 (19). The probes were labeled at the 3 ' end using $\alpha-{ }^{35}$ S-dATP (New England Nuclear, Boston, MA) and terminal deoxynucleotidyl transferase (Boehringer-Mannheim, Mannheim, Germany), as described previously (17). Autoradiographic images were digitalized using a MacIntosh II-based image analysis system (IMAGE, W. Rasband, Research Services Branch, National Institute of Mental Health). The optic density of the supraoptic (SON), suprachiasmatic ( $\mathrm{SCN}$ ), and PVN were converted to disintegrations per minute per milligram or to microcuries per gram of tissue for CRF and AVP respectively, using standard curves generated with ${ }^{35} \mathrm{~S}$ standards.

Serum biochemical liver tests. Serum alkaline phosphatase and bilirubin were determined in a commercial laboratory (MetPath, Kensington, MD).

Statistical analyses. Data are expressed as means \pm SEM. An unpaired Student's $t$ test was used for comparisons between two means, and an ANOVA followed by Duncan's New Multiple Range test for comparisons among more than two means.

\section{Results}

Characterization of the cholestasis model. BDR rats showed clinical evidence of cholestasis with jaundice, dark urine, and icteric plasma. Cholestasis in these animals was confirmed biochemically by the demonstration of a marked elevation of plasma bilirubin and alkaline phosphatase (bilirubin: BDR $9.5 \pm 2.5 \mathrm{mg} / \mathrm{dl}$, sham resected $0.2 \pm .05 \mathrm{mg} / \mathrm{dl}$; alkaline phosphatase: BDR 1,254 $\pm 885 \mathrm{IU} /$ liter, sham resected $415 \pm 67 \mathrm{IU} /$ liter; values for unoperated controls were similar to those for sham operated animals). The size of the adrenal glands from BDR, unoperated control, and sham-resected rats were similar when expressed as milligrams of adrenal wet weight per gram of body weight (BDR: $0.26 \pm .08 \mathrm{mg} / \mathrm{g}$ body wt.; sham resected: $0.23 \pm .04 \mathrm{mg} / \mathrm{g}$ body wt.; unoperated control: $0.22 \pm .04 \mathrm{mg} / \mathrm{g}$ body wt.; $P=$ NS).

Ether stress. Basal unstressed plasma ACTH and corticosterone levels were similar in BDR, sham-resected, and unoperated control rats ( $P=\mathrm{NS}$; Figs. 1 and 2$)$. Exposure to ether for $1 \mathrm{~min}$ was associated with a twofold increase in plasma ACTH levels in BDR rats but 4.7-fold and fourfold increases in plasma 


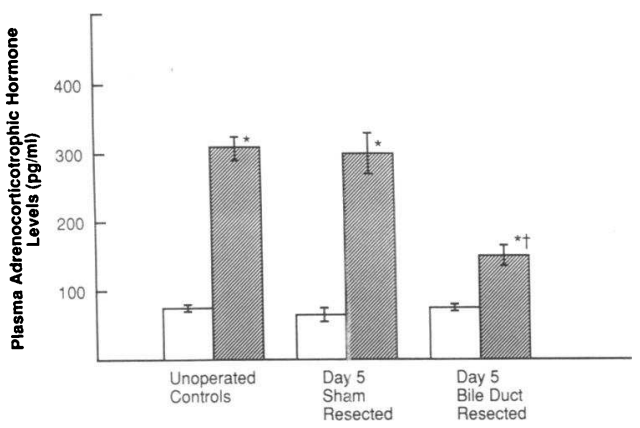

Figure 1. Plasma adrenocorticotrophic hormone levels in unoperated controls, sham-resected, and bile duct-resected rats $5 \mathrm{~d}$ after surgery. Open bars, unstressed rats; hatched bars, rats exposed to ether vapor for $1 \mathrm{~min}$ and killed $2 \mathrm{~min}$ after ether exposure. Bars represent the mean \pm SEM of data from eight animals. ${ }^{*} P \leq .01$ vs corresponding levels in unstressed rats; ${ }^{+} P \leq .01$ vs levels in ether stressed unoperated and sham-resected animals.

ACTH levels in sham-resected and unoperated control animals, respectively $(P \leq .01$; Fig. 1$)$. These ether-induced elevations of plasma ACTH levels were accompanied by elevations in plasma corticosterone levels. After exposure to ether, plasma corticosterone levels rose 11.2-fold and 7.9-fold in unoperated control and sham-resected rats, respectively. The poststress absolute plasma corticosterone levels in these groups were similar $(497 \pm 30.5 \mathrm{ng} / \mathrm{ml}$ vs $477 \pm 52.1 \mathrm{ng} / \mathrm{ml}, P=$ NS; Fig. 2$)$. In contrast, in BDR animals, post-ether stress plasma corticosterone levels were increased only fivefold and these levels were significantly less than in the other two groups $(P \leq .01$; Fig. 2$)$.

Ovine CRF administration. Plasma ACTH levels determined in truncal blood $30 \mathrm{~min}$ after the administration of ovine CRF were significantly lower in BDR animals than in sham-resected controls (BDR: $531.5 \pm 36.5 \mathrm{pg} / \mathrm{ml}$ vs sham-resected: $729.8 \pm 57.0 \mathrm{pg} / \mathrm{ml} ; n=8 ; P \leq .005)$.

Hypothalamic CRF and AVP content and basal release. Values for hypothalamic CRF content were similar in unoperated control and sham-operated rats and were significantly higher than those for BDR rats (BDR: ${ }^{*} 93.2 \pm 6.7 \mathrm{pg} / \mathrm{mg}$ pro-

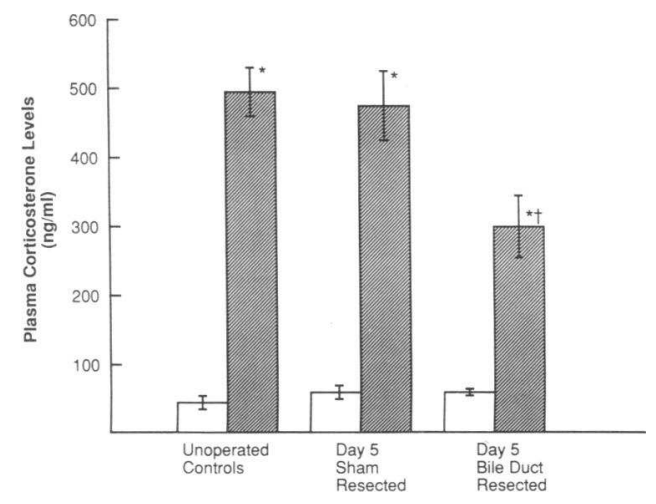

Figure 2. Plasma corticosterone levels in unoperated controls, shamresected, and bile duct-resected rats $5 \mathrm{~d}$ after surgery. Open bars, unstressed animals; hatched bars, rats exposed to ether vapor for $1 \mathrm{~min}$ and killed $20 \mathrm{~min}$ after ether exposure. Bars represent the mean \pm SEM of data from eight animals. ${ }^{*} P \leq .01$ vs corresponding levels in unstressed rats; ${ }^{\dagger} P \leq .01$ vs levels in ether stressed unoperated and sham resected animals.

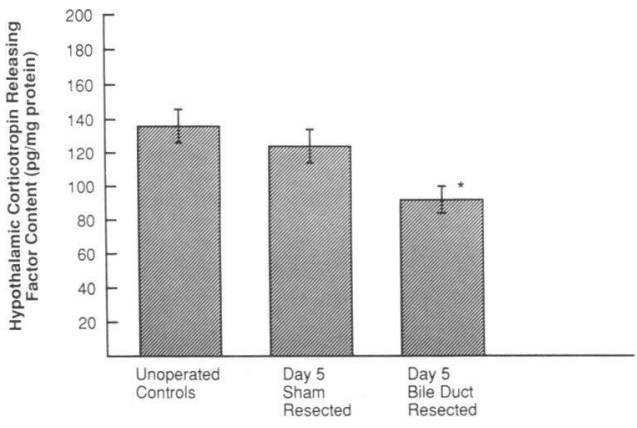

Figure 3. Hypothalamic corticotropin releasing factor content in unoperated control, sham-resected, and bile duct-resected rats $5 \mathrm{~d}$ after surgery. Bars represent the mean \pm SEM of data from 14 animals. ${ }^{*} P$ $\leq .01$ vs levels in unoperated control and $P \leq .05$ vs levels in shamresected animals.

tein; sham resected: $124.9 \pm 11.1 \mathrm{pg} / \mathrm{mg}$ protein; unoperated controls: $135.9 \pm 12.2 \mathrm{pg} / \mathrm{mg}$ protein; ${ }^{*} P \leq .01 \mathrm{BDR}$ vs unoperated controls and ${ }^{*} P \leq .05$ vs sham operated controls [Fig. 3]). Hypothalamic AVP contents were also similar in sham-resected and unoperated controls $(P=\mathrm{NS})$. However, in contrast to the CRF data, BDR rats had a significant elevation of hypothalamic AVP content (BDR: *353.0 $\pm 19.5 \mathrm{pg} / \mathrm{mg}$ protein; sham resected controls: $261.4 \pm 26.8 \mathrm{pg} / \mathrm{mg}$ protein; unoperated controls: $239.8 \pm 18.1 \mathrm{pg} / \mathrm{mg}$ protein; Fig. $4 ;{ }^{*} P \leq .01$ vs unoperated and sham-resected controls).

In vitro basal $C R F$ release obtained from the hypothalamic explants of sham operated and BDR rats was 16 and 35\% less than that for unoperated controls, respectively $(P \leq .05$ and $P$ $\leq .01$, respectively) (Fig. 5). In addition, basal CRF release was significantly lower in BDR than in sham-operated animals (BDR: $23.3 \pm 1.8 \mathrm{pg} / \mathrm{ml}$ vs sham operated: $30.4 \pm 1.7 \mathrm{pg} / \mathrm{ml} ; P$ $\leq .01$; (Fig. 5). Values for the in vitro release of AVP from hypothalamic explants from unoperated control and sham-resected animals were similar (Fig. 6, $P=\mathrm{NS}$ ). However, in contrast to the CRF data, basal hypothalamic secretion of AVP was about $24 \%$ higher in BDR animals than in unoperated and sham-resected controls (BDR: ${ }^{*} 143.8 \pm 7.1 \mathrm{pg} / \mathrm{ml}$ media; sham-resected controls: $115.7 \pm 6.9 \mathrm{pg} / \mathrm{ml}$ media; unoperated controls: $102.8 \pm 3.8 \mathrm{pg} / \mathrm{ml}$ media; [Fig. 6 ] $P \leq .01$ vs unoperated and sham resected controls).

Hypothalamic CRF and AVP in situ hybridization. The CRF mRNA hybridization signals obtained in sham operated

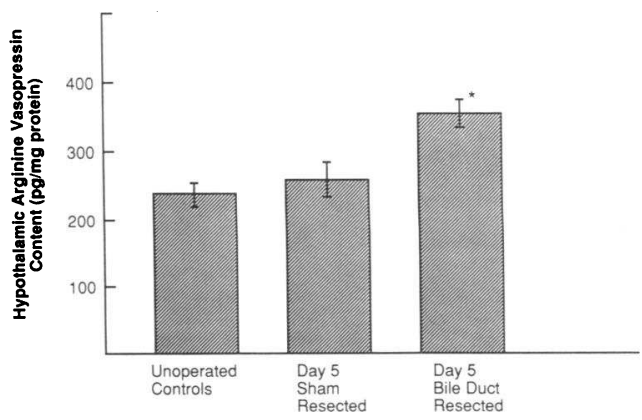

Figure 4. Hypothalamic arginine vasopressin content in unoperated control, sham-resected, and bile duct-resected rats $5 \mathrm{~d}$ after operation. Bars represent the mean \pm SEM of data from 12 animals. ${ }^{*} P \leq .01$ vs sham-resected and unoperated control rats. 


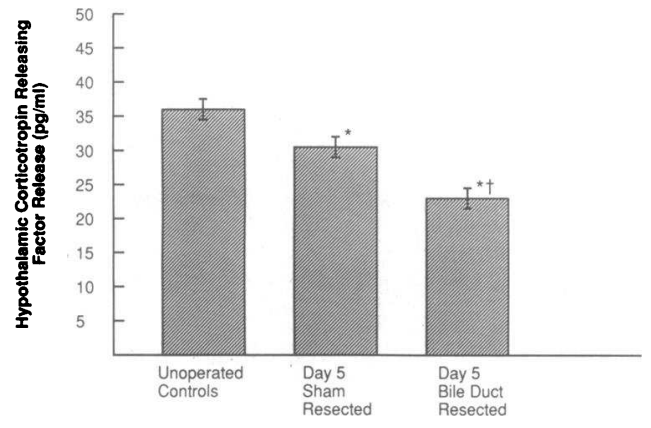

Figure 5. Corticotropin-releasing factor basal in vitro release from hypothalamic explants from unoperated control, sham-resected, and bile duct-resected rats $\mathbf{5} \mathrm{d}$ after surgery. Bars represent the mean \pm SEM of data from six animals. ${ }^{*} P \leq .05$ for sham-resected and $P \leq .01$ for bile duct-resected animals vs unoperated control rats; ${ }^{\dagger} P$ $\leq .01$ vs sham-resected and unoperated control animals.

and unoperated controls were similar $(P=\mathrm{NS})$. However, the CRF mRNA hybridization signal in the paraventricular nucleus in BDR rats was less than that in unoperated and sham operated controls (BDR: * $133.0 \pm 3.2 \mathrm{dpm} / \mathrm{mg}$ tissue; sham resected: $211.3 \pm 5.1 \mathrm{dpm} / \mathrm{mg}$ tissue; unoperated control; $223.4 \pm 12.9 \mathrm{dpm} / \mathrm{mg}$ tissue; ${ }^{*} P \leq .01$ [Fig. 7]). AVP mRNA hybridization signals were similar in the $\mathrm{SCN}$ of the three study groups (BDR: $1.4 \pm 0.1 \mu \mathrm{Ci} / \mathrm{g}$ tissue; sham resected controls: $1.4 \pm 0.1 \mu \mathrm{Ci} / \mathrm{g}$ tissue; unoperated controls: $1.3 \pm 0.1 \mu \mathrm{Ci} / \mathrm{g}$ tissue; [Fig. $8 a$ ] $P=$ NS). This finding was paralleled by the mRNA hybridization signals obtained for AVP in the SON, which were also similar in the three study groups (BDR: $7.0 \pm 0.4 \mu \mathrm{Ci} / \mathrm{g}$ tissue; sham-resected controls: $6.3 \pm 0.5 \mu \mathrm{C} \mathrm{i} / \mathrm{g}$ tissue; unoperated controls: $7.0 \pm 0.7 \mu \mathrm{Ci} / \mathrm{g}$ tissue [Fig. $8 \vec{b}$ ] $P$ $=\mathrm{NS})$. However, in contrast to the findings in the $\mathrm{SCN}$ and SON, AVP mRNA expression in the PVN was greater in BDR rats than in unoperated and sham-resected controls, which demonstrated similar PVN AVP mRNA expression (BDR: *26.1 $\pm 3.1 \mu \mathrm{Ci} / \mathrm{g}$ tissue; sham-resected controls: $3.9 \pm 0.4 \mu \mathrm{Ci} / \mathrm{g}$ tissue; unoperated controls: $4.0 \pm 0.4 \mu \mathrm{Ci} / \mathrm{g}$ tissue; Fig. $8 c ;{ }^{*} P$ $\leq .01$ vs unoperated and sham-resected controls).

Pituitary ACTH content. Pituitary protein content was similar in BDR, sham-resected and unoperated control groups (BDR $798 \pm 40.1 \mathrm{mg}$ protein/pituitary vs sham resected $782 \pm 59.7 \mathrm{mg}$ protein/pituitary vs unoperated controls

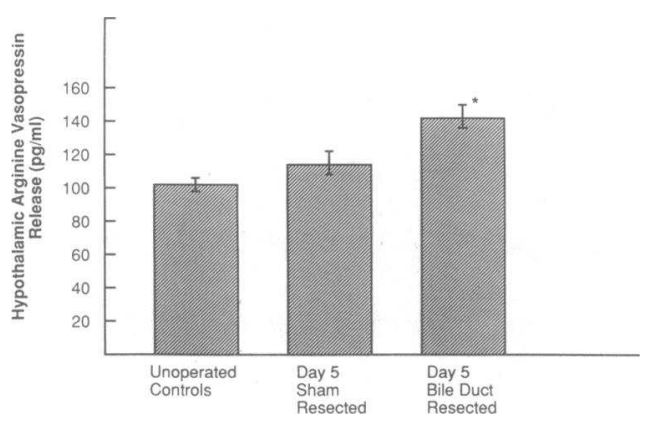

Figure 6. Basal in vitro arginine vasopressin release from hypothalamic explants in unoperated control, sham-resected, and bile ductresected rats $5 \mathrm{~d}$ after operation. Bars represent the mean \pm SEM of data from 18 animals. ${ }^{*} P \leq .01$ vs unoperated control and sham-resected animals.

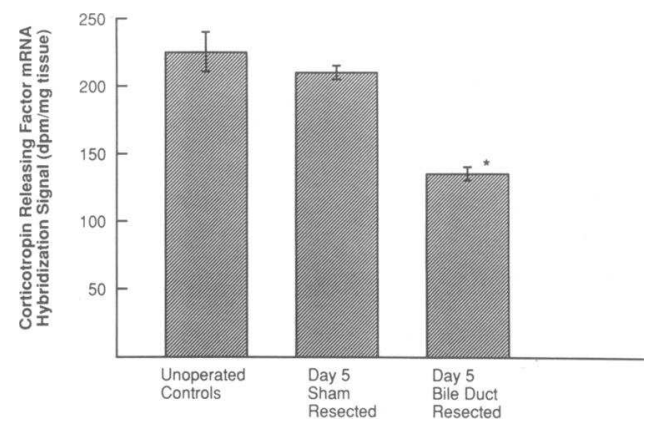

Figure 7. Hypothalamic paraventricular nucleus corticotropin-releasing factor mRNA expression in unoperated control, sham-resected, and bile duct-resected rats $5 \mathrm{~d}$ after surgery. Bars represent the mean \pm SEM of data from six animals. ${ }^{*} P \leq .01$ vs sham-resected and unoperated control rats.

$985 \pm 94.6 \mathrm{mg}$ protein $/$ pituitary, $n=8$ per group, $P=\mathrm{NS}$ ). Values for pituitary ACTH content in both sham-resected and BDR rats were similar and were higher than those for unoperated control animals (BDR: $260 \pm 28.1 \mathrm{ng} / \mathrm{mg}$ protein; sham resected: $247 \pm 26.0 \mathrm{ng} / \mathrm{mg}$ protein; unoperated control: $159 \pm 16.5 \mathrm{ng} / \mathrm{mg}$ protein [Fig. 9] $P \leq .01$ for both groups vs unoperated controls).

\section{Discussion}

The results of this study demonstrate that in rats with unequivocal acute cholestasis there is a significant suppression of the responsiveness of the HPA axis to stress. In the absence of exogenous stress, however, baseline plasma ACTH and total corticosterone levels in BDR rats were similar to those in shamoperated and unoperated control rats. These findings are consistent with the normal adrenal weights of BDR animals and with the normal basal plasma levels of ACTH and cortisol documented in humans with liver diseases (20). Our results contrast with results from studies in rats using chronic stress paradigms, such as chronic exposure to cold or recurrent restraint, in which, after several days of exposure to stress, basal plasma

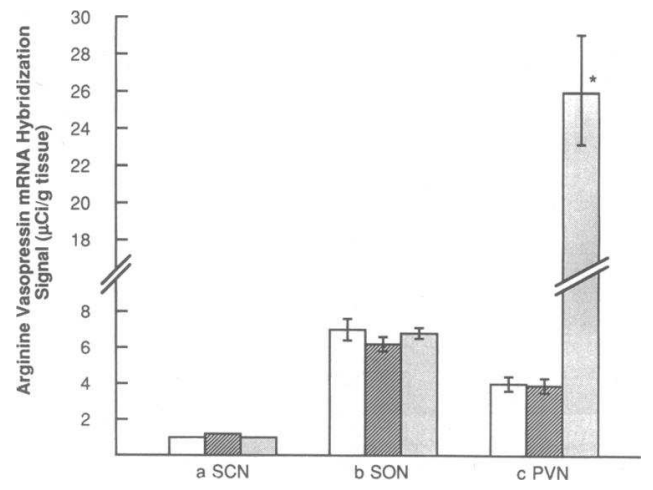

Figure 8. Arginine vasopressin mRNA expression in the three main vasopressin containing nuclei of the hypothalamus: $(a)$ suprachiasmatic $(S C N),(b)$ supraoptic $(S O N)$ and $(c)$ paraventricular $(P V N)$ in unoperated (open bars), sham-resected (hatched bars), and bile duct-resected (stippled bars) rats $5 \mathrm{~d}$ after the operation. Bars represent the means \pm SEM of data on five animals. ${ }^{*} P \leq .01$ vs unoperated control and sham resected animals. 


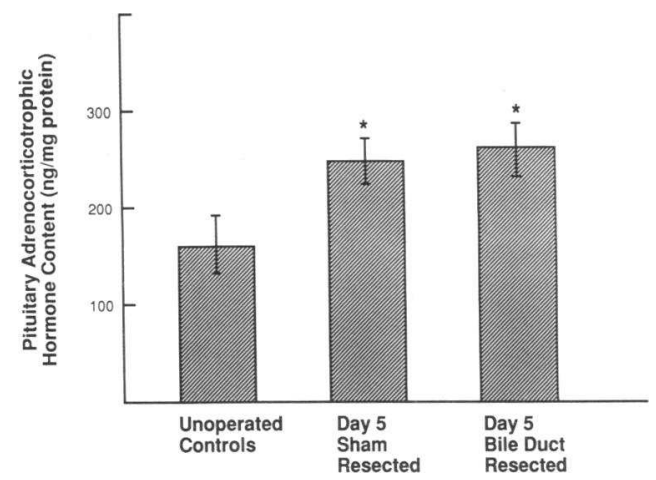

Figure 9. Pituitary adrenocorticotrophic hormone levels in unoperated control, sham-resected, and bile duct-resected rats $5 \mathrm{~d}$ after surgery. Bars represent the mean \pm SEM of data from eight animals. ${ }^{*} P$ $\leq .01$ vs levels in unoperated control animals.

corticosterone levels and adrenal weights were higher than those of unstressed control rats $(21,22)$.

The increase in plasma ACTH after exposure to saturated ether vapor, a well-described systemic stressor in rats (13), was attenuated $5 \mathrm{~d}$ after BDR. Ether stress induced a similar pattern of ACTH release in rats $10 \mathrm{~d}$ after BDR, suggesting that the defect in responsiveness is not a transient phenomenon (data not shown). Exposure of chronically stressed animals to an acute novel stress is usually associated with a striking augmentation in the stress-induced increase of plasma ACTH and/or corticosterone levels (21-23), which is opposite to the corresponding changes we observed in BDR rats. This finding suggests that the altered response of BDR rats to stress is not attributable to chronic stress related to BDR, but rather to the cholestatic syndrome itself.

Decreased release of ACTH in BDR rats in response to stress cannot be attributed to diminished pituitary ACTH content, as both the BDR and sham-resected rats had increased anterior pituitary ACTH concentrations compared to the unoperated animals. Increases in pituitary ACTH content of similar magnitude have been documented in rats exposed to chronic restraint stress (21). In BDR rats, hypothalamic CRF content was significantly less than that of sham-resected and unoperated control rats. This observation contrasts with the findings of Hashimoto et al., who demonstrated similar hypothalamic CRF contents in rats exposed to chronic restraint stress and unstressed controls (21). Thus, the diminished hypothalamic CRF content in BDR rats does not appear to be attributable to chronic stress per se. Furthermore, the finding of similar hypothalamic CRF contents in sham-operated and unoperated control animals indicate that reduced hypothalamic CRF content in BDR rats is not the consequence of laparotomy alone, but is probably directly related to the cholestatic syndrome. The decrease in hypothalamic CRF content in BDR rats was paralleled by a striking reduction in hypothalamic CRF mRNA levels in these animals and by a decrease in hypothalamic CRF release in vitro. These findings suggest that diminished hypothalamic CRF content and secretion in BDR rats may be caused by a lesion at the transcriptional level.

In contrast to the hypothalamic CRF findings, BDR rats demonstrated enhanced hypothalamic AVP content, release, and mRNA expression. The increase in hypothalamic AVP content appears to be secondary to enhanced AVP gene expres- sion in the PVN. AVP neurons from the PVN and SON both project to the posterior pituitary and release AVP into the systemic circulation in response to osmotic stimuli (24). Dehydration has been shown to result in enhanced AVP gene expression in both the PVN and SON (25). However, in BDR rats AVP mRNA expression was increased only in the parvocellular component of the PVN, suggesting that the abnormal mRNA expression is not related to dehydration. Consistent with this finding is the recent description of normal plasma AVP levels in rats $5 \mathrm{~d}$ after BDR (26). Therefore, increased hypothalamic AVP mRNA content and secretion may occur as a homeostatic compensatory mechanism to the suppressed hypothalamic CRF release in cholestasis. Indeed, exogenous administration of ovine CRF demonstrated diminished corticotroph responsiveness in BDR rats compatible with decreased CRF priming of corticotrophs in BDR animals. In further support of this hypothesis is the recent report that increased AVP secretion from the hypothalamus stimulates more corticotrophs in the anterior pituitary to secrete $\mathrm{ACTH}$, whereas increasing concentrations of CRF stimulate more ACTH secretion per cell (27).

We have previously documented a striking elevation of plasma endogenous opioid activity in BDR rats (9). Opioid peptides are known to suppress hypothalamic CRF secretion in vitro (28) and exposure of rats to morphine for $5 \mathrm{~d}$ reduces the capacity of the hypothalamus to secrete CRF (29). We have demonstrated that BDR rats exhibit decreased basal CRF release from hypothalamic explants in vitro, suggesting that there is a lesion at the hypothalamic level in cholestasis. Whether, and to what extent, this is related to the marked increase in plasma opioid activity documented in this model of cholestasis is currently unknown.

A number of cytokines are known to acutely interact with and stimulate the HPA axis (30-32). Recently, in rats with adjuvant-induced arthritis, mild chronic hypercorticosteronism was associated with diminished hypothalamic CRF release and CRF mRNA expression in the hypothalamus, as well as enhanced AVP mRNA expression and release from the hypothalamus (33). Adjuvant treated arthritic animals would be expected to have elevated circulating inflammatory cytokines such as TNF-alpha, IL-1 and IL-6. Increased levels of plasma cytokines have been documented in cholestatic patients (7) and BDR mice (6). Chronically elevated levels of cytokines have been associated with impairment in the activation of the HPA axis in states such as rheumatoid arthritis $(34,35)$ and sleeping sickness (36). In addition, in patients with extensive burns, TNF-alpha levels in plasma correlate negatively with plasma cortisol concentrations (37). Therefore, elevated plasma cytokine levels may contribute to the abnormalities in hypothalamic CRF and AVP demonstrated in the BDR rat model of cholestasis.

In summary, we have documented a diminished plasma $\mathrm{ACTH}$ and corticosterone response in BDR rats exposed to a strong systemic stressor. This defect appears to be caused in part by decreased CRF synthesis and secretion from the hypothalamus. The observed suppression of hypothalamic CRF activity in BDR rats is associated with an enhancement of hypothalamic AVP synthesis and secretion. The results suggest that the responsiveness of the HPA axis during periods of maximal stress in cholestasis may be inadequate and may, therefore, contribute to the enhanced surgical morbidity and mortality documented in cholestatic patients. 


\section{Acknowledgments}

Mark G. Swain was supported by the Canadian Liver Foundation.

\section{References}

1. Zollinger, R. M., and R. D. Williams. 1956. Surgical aspects of jaundice. Surgery (St. Louis). 30:1016-1030.

2. Williams, R. D., D. W. Elliott, and R. M. Zollinger. 1960. The effect of hypotension in obstructive jaundice. Arch. Surg. 81:334-340.

3. Dawson, J. L. 1963. Acute post-operative renal failure in obstructive jaundice. Ann. R. Coll. Surg. Engl. 42:163-181.

4. Baxter, J. D. 1988. Adrenocortical hypofunction. In Cecil Textbook of Medicine. J. B. Wyngaarden and L. H. Smith, editors. W. B. Saunders Co., Philadelphia. 1351-1353.

5. Merry, J., and V. Marks. 1973. Hypothalamic-pituitary-adrenal function in chronic alcoholics. In Alcohol Intoxication and Withdrawal: Experimental Studies. Advances in Experimental Medicine and Biology. M. M. Gross, editor. Plenum Press, New York. 167-179.

6. Bemelmans, M. H. A., D. J. Gouma, J. W. Greve, and W. A. Buurman. 1992. Cytokines tumor necrosis factor and interleukin- 6 in experimental biliary obstruction in mice. Hepatology. 15:1132-1136.

7. Haga, Y., K. Sakamoto, H. Egami, Y. Yokoyama, M. Arai, K. Mori, and M. Akagi. 1981. Changes in production of interleukin-1 and interleukin-2 associated with obstructive jaundice and biliary drainage in patients with gastrointestinal cancer. Surgery (St. Louis). 106:842-848.

8. Thornton, J. R., and M. S. Losowsky. 1988. Opioid peptides and primary biliary cirrhosis. Br. Med. J. 297:1501-1504.

9. Swain, M. G., R. B. Rothman, H. Xu, J. Vergalla, N. V. Bergasa, and E. A. Jones. 1992. Endogenous opioids accumulate in plasma in a rat model of acute cholestasis. Gastroenterology. 103:630-635.

10. Vale, W. J. Spiess, C. Rivier, and J. Rivier. 1981. Characterization of a 4 residue ovine hypothalamic residue that stimulates the secretion of corticotropin and B-endorphin. Science (Wash. DC). 213:1394-1397.

11. Gillies, G. E., E. A. Linton, and P. J. Lowry. 1982. Corticotropin releasing

activity of the new CRF is potentiated several times by vasopressin. Nature (Lond.). 299:355-357.

12. Cameron, G. R., and C. L. Oakley. 1932. Ligation of the common bile duct. J. Pathol. Bacteriol. 35:769-798.

13. Nakane, Y., T. Audhya, N. Kanie, and C. S. Hollander. 1985. Evidence for a role of endogenous corticotropin-releasing factor in cold, ether, immobilization and traumatic stress. Proc. Natl. Acad. Sci. USA. 82:1247-1251.

14. Buckingham, J. C., and T. A. Cooper. 1986. Effects of naloxone on hypothalamo-pituitary-adrenocortical activity in the rat. Neuroendocrinology. 42:421-426.

15. Calogero, A., R. Bernardini, A. Margioris, G. Bagdy, W. Gallucci, P. Munson, L. Tamarkin, T. P. Tomai, L. Brady, P. W. Gold, and G. P. Chrousos 1989. Effects of serotonergic agonists and antagonists on corticotropin-releasing hormone secretion by explanted rat hypothalami. Peptides. 10:189-200.

16. Lowry, O. H., A. Rosebrough, A. L. Farr, and R. J. Randall. 1951. Protein measurement with the folin phenol reagent. J. Biol. Chem. 193:265-275.

17. Brady, L. S., M. A. Smith, P. W. Gold, and M. Herkenham. 1990. Altered expression of hypothalamic neuropeptide mRNAs in food-restricted and fooddeprived animals. Neuroendocrinology. 52:441-447.

18. Ivell, R., and D. Richter. 1984. Structure and comparison of the oxytocin and vasopressin genes from rat. Proc. Natl. Acad. Sci. USA. 81:2006-2010.

19. Jingami, H., N. Mizuno, H. Takahashi, S. Shibahara, Y. Furutani, H. Imura, and S. Numa. 1985. Cloning and sequence analysis of cDNA for rat corticotropin-releasing factor precursor. FEBS (Fed. Eur. Biochem. Soc.) Lett. 191:63-66.
20. Van Thiel, D. A. 1988. The liver and the endocrine system. In The Liver: Biology and Pathobiology. 2nd ed. I. M. Arias, W. B. Jacoby, H. Popper, D. Schachter, and D. A. Shafritz, editors. Raven Press Ltd., New York. 1007-1031.

21. Hashimoto, K., S. Suemaru, T. Takao, M. Sugawara, S. Makino, and Z. Ota. 1988. Corticotropin-releasing hormone and pituitary-adrenocortical responses in chronically stressed rats. Regul. Pept. 23:117-126.

22. Vernikos, J., M. F. Dallman, C. Bonner, A. Katzen, and J. Shinsako. Pituitary-adrenal function in rats chronically exposed to cold. Endocrinology. 110:413-420.

23. Daniels-Severs, A., A. Goodwin, L. C. Keil, and J. Vernikos-Danellis. Effect of chronic crowding and cold on the pituitary-adrenal system: responsiveness to an acute stimulus during chronic stress. Pharmacology. 1973; 9:348-354.

24. Andreoli, T. E. 1988. The posterior pituitary. 1988. In Cecil Textbook of Medicine. J. B. Wyngaarden and L. H. Smith, editors. W. B. Saunders Co., Philadelphia. 1305-1313.

25. Uhl, G. R., H. H. Zingg, and J. F. Habener. 1985. Vasopressin mRNA in situ hybridization: localization and regulation studied with oligonucleotide cDNA probes in normal and Brattleboro rat hypothalamus. Proc. Natl. Acad. Sci. USA. 82:5555-5559.

26. Sharma, A., Y. Yagil, and N. Vakil. 1992. Water handling after bile duct ligation (BDL) in the rat. Gastroenterology. 102:886a. (Abstr.)

27. Conny, B. J., L-G Jia, and D. A. Leong. 1992. Corticotropin-releasing factor, but not arginine-vasopressin, stimulates concentration-dependent increases in ACTH secretion from a single corticotrope. J. Biol. Chem. 267:83258329.

28. Calogero, A. E., W. T. Gallucci, P. W. Gold, and G. P. Chrousos. 1988. Multiple feedback regulatory loops upon rat hypothalamic corticotropin-releasing hormone secretion. J. Clin. Invest. 82:767-774.

29. Buckingham, J. C., and T. A. Cooper. 1984. Differences in hypothalamopituitary-adrenocortical activity in the rat after acute and prolonged treatment with morphine. Neuroendocrinology. 38:411-417.

30. Sharp, B. M., S. G. Matta, P. K. Peterson, R. Newton, C. Chao, and K. McAllen. 1989. Tumour necrosis factor-alpha is a potent ACTH secretogogue: comparison to interleukin-1 $\beta$. Endocrinology. 124:3131-3133.

31. Sapolsky, R., C. Rivier, G. Yamamoto, P. Plotsky, and W. Vale. 1987. Interleukin-1 stimulates the secretion of hypothalamic corticotropin-releasing factor. Science (Wash. DC). 238:522-524.

32. Naitoh, Y., J. Fukata, T. Tominaga, Y. Nakai, S. Tamai, K. Mori, and H. Imura. 1988. Interleukin-6 stimulates the secretion of adrenocorticotrophic hormone in conscious, freely moving rats. Biochem. Biophys. Res. Commun. 155:1459-1463

33. Harbuz, M. S., R. G. Rees, D. Eckland, D. S. Jessop, D. Brewerton, and S. L. Lightman. 1992. Paradoxical responses of hypothalamic corticotropin releasing factor (CRF) messenger ribonucleic acid (mRNA) and CRF-41 peptide and adenohypophyseal proopiomelanocortin mRNA during chronic inflammatory stress. Endocrinology. 130:1394-1400.

34. Chikanza, I. C., P. Petrou, G. P. Chrousos, G. Kingsly, and G. Panayi. 1992. Defective hypothalamic response to immune/inflammatory stimuli in patients with rheumatoid arthritis. Arthritis \& Rheum. 35:1281-1288.

35. Harbuz, M. S., and R. G. Rees. 1992. Effect of adrenalectomy on hypothalamic messenger RNA during the development of adjuvant-induced arthritis in the rat. 74th Annual Meeting, The Endocrine Society, San Antonio, TX. 941. (Abstr.)

36. Reinche, M., F. Petzke, C. Heppner, W. Arlt, D. Mbulamberi, and W. Winkelmann. 1992. Combined hypocorticolism, hypothyroxemia and hypogonadism in patients with African sleeping sickness: need for replacement therapy? 74th Annual Meeting, The Endocrine Society, San Antonio, TX. 1113. (Abstr.)

37. Marano, M. A., Y. Fong, L. L. Moldawer, H. Wei, S. E. Calvano, K. J. Tracey, P. S. Barie, K. Monogue, A. Cerami, G. T. Shires, and S. F. Lowry. 1990. Serum cachectin/tumour necrosis factor in critically ill patients with burns correlates with infection and mortality. Surg. Gynecol. \& Obstet. 170:32-38. 